\title{
KEBIJAKAN FORMULASI TERKAIT KONSEPSI RECHTERLIJKE PARDON (PERMAAFAN HAKIM) DALAM PEMBAHARUAN HUKUM PIDANA DI INDONESIA
}

\author{
Aska Yosuki \\ (Mahasiswa Program S1 Fakultas Hukum Universitas Tarumanagara) \\ (E-mail: Askayosuki1996@gmail.com) \\ Dian Adriawan Daeng Tawang \\ (Corresponding Author) \\ (Dosen Hukum Pidana, Universitas Tarumanagara dan Universitas Trisakti, Meraih Sarjana Hukum \\ dari Universitas Hasanuddin, Magister Hukum dari Universitas Hasanuddin, dan Doktor Ilmu Hukum \\ dari Universitas Hasanuddin) \\ (E-mail: dian.adriawan@gmail.com)
}

\begin{abstract}
The effort of reforming criminal law in Indonesia, particularly the regulations, has been conducted since 1963, proven by the formulation of Penal Code Bill, however, until now, the Penal Code Bill has not been passed. One of the ideas in the Penal Code Bill is the concept of Rechterlijk Pardon. This concept is crystallized because of the current criminal law is too rigid and lack of humanity sense in applying to minor cases. This research aims to describe the concept of Rechterlijk Pardon and the basis of the concept in the Penal Code Bill in Indonesia. The result of the research is that the concept of Rechterlijk Pardon desires that in imposing criminal sanctions, the judges shall not only consider the criminal act and criminal responsibility, but also the objectives and guidelines of imposing criminal sanctions. The objectives and guidelines have been explicitly regulated in Article 55 and 56 of Penal Code Bill. Whenever the judges believe that imposing criminal sanctions is not consistent with its purpose and guidelines, the judges is possible to give pardon. The essence of this concept is that when the prosecutor successfully proves its indictment and the perpetrator was given pardon by the judges, there will be no criminal sanctions that will be imposed on the perpetrator. The form of the verdict is a guilty verdict without punishment. The basis of this concept are the philosophical, sociological, juridical, and teoritical basis.
\end{abstract}

Keywords: Rechterlijk Pardon, Penal Code Bill, Imposing Criminal Sanctions 


\section{Pendahuluan}

\section{A. Latar Belakang}

Pembaharuan hukum pidana pada tataran regulasi telah diupayakan oleh lembaga pembentuk undang-undang sejak tahun 1963, dengan disusunnya Rancangan Kitab Undang-Undang Hukum Pidana (selanjutnya disebut RUU KUHP). Namun sampai saat ini, pemerintah belum juga berhasil membuat kodifikasi peraturan induk hukum pidana yang didasarkan nilai-nilai yang ada di dalam Pancasila serta Pembukaan UUD 1945. Konsekuensi dari belum disahkannya RUU KUHP adalah, Negara Indonesia tetap menggunakan Kitab Undang-Undang Hukum Pidana (KUHP) peninggalan pemerintah HindiaBelanda yang tentunya telah tertinggal oleh kemajuan yang terjadi dalam kehidupan masyarakat.

Dalam melakukan pembaharuan hukum pidana, tentunya perlu memperhatikan pernyataan dari Konggres PBB yang berkaitan dengan pemberlakuan hukum asing/impor pada suatu negara. Dalam Konggres PBB mengenai "The Prevention of Crime and The Treatment of offenders" disampaikan bahwa sistem hukum pidana yang selama ini ada di beberapa negara (terutama yang berasal dari hukum asing semasa zaman kolonial) pada umumnya bersifat "Obsolote and Unjust" (telah usang dan tidak adil) serta "Outmoded and Unreal" (sudah ketinggalan zaman dan tidak sesuai kenyatataan). ${ }^{1}$

Alasan mengapa penting dilakukannya pembaharua hukum pidana di Indonesia menurut Seodarto, antara lain: ${ }^{2}$

1. Alasan politik: Negara Indonesia yang telah lima puluh tahun lebih merdeka adalah wajar mempunyai hukum pidana sendiri yang diciptakannya sendiri oleh karena hal ini merupakan simbol kebanggaan dari negara yang telah bebas dari penjajahan.

\footnotetext{
${ }^{1}$ Barda Nawawi Arief, Beberapa Aspek Kebijakan Penegakan dan Pengembangan Hukum Pidana, (Bandung: Citra Aditya Bakti, 1998), hlm. 103.

${ }^{2)}$ Ali Zaidan, Menuju Pembaharuan Hukum Pidana, (Jakarta: Sinar Grafika, 2015), hlm. 59.
} 
2. Alasan sosiologis: Pengaturan dalam hukum pidana merupakan pencerminan dari ideologi, politik suatu bangsa di mana hukum itu berkembang artinya bahwa segala nilai-nilai sosial dan kebudayaan suatu bangsa itu harus mendapat tempat dalam pengaturan hukum pidana.

3. Alasan Praktis: dengan pembaharuan hukum pidana yang baru akan dapat memenuhi kebutuhan praktik, sebab hukum peninggalan penjajah jelas masih menggunakan bahasa Belanda, padahal kita sebagai negara yang merdeka sudah memiliki bahasa sendiri, tentunya tidaklah tepat jika menrapkan suatu aturan hukum berdasarkan teks yang tidak asli.

Ketiga alasan yang menjadi dasar pembaharuan hukum pidana sebagaimana yang disampaikan Soedarto, tersirat bahwa dalam melakukan pembaharuan hukum pidana seharusnya dilakukan secara menyeluruh, bersifat komprehensif serta disesuaikan dengan nilai-nilai yang hidup di masyarakat sehingga hukum yang dicita-citakan (Ius Constituendum) lebih mendekatkan pada karakter masyarakat Indonesia yang bersifat monodualistis dan pluralistik.

Muladi menyampaikan bahwa di samping ketiga alasan dilakukan pembaharuan hukum pidana yang disampaikan oleh Soedarto, sebagai bangsa yang tidak dapat lepas dari pergaulan bangsa-bangsa di dunia maka alasan adaptif tidak dapat dikesampingkan, artinya upaya pembaharuan di masamasa yang akan datang harus dapat menyesuaikan diri dengan perkembanganperkembangan baru khususnya perkembangan Internasional yang bergerak cepat. ${ }^{3}$ Salah satu ide yang muncul dalam perkembangan internasional adalah Konsepsi Rechterlijk Pardon (Permaafan Hakim). Negara yang pertama kali memunculkan konsepsi ini adalah Negara Belanda. ${ }^{4}$ Beberapa negara di dunia

\footnotetext{
${ }^{3)}$ Muladi, Proyeksi Hukum Pidana Materiil Indonesia di Masa Datang (Pidato Pengukuhan), (Semarang: BP UNDIP, 1995), hlm. 145.

${ }^{4)}$ Pasal 9a KUHP Belanda, "The Judge may determine in the judgement that no punishment or measure.shall be imposed, where he deems his advisable, by reason of the lack gravity of the offense,
} 
juga telah menunculkan Konsepsi Rechterlijk Pardon (Permaafan Hakim) ke dalam peraturan hukum pidananya salah satunya adalah Negara Portugal. ${ }^{5}$

Negara Indonesia juga merespon adanya Konsepsi Rechterlijk Pardon (Permaafan Hakim), terlihat dalam RUU KUHP yang memunculkan konsepsi tersebut. Konsepsi Rechterlijk Pardon (Permaafan Hakim) dianggap sesuai dengan nilai-nilai hukum yang hidup dan nilai hukum nasional yang lebih berorientasi pada nilai Pancasila. Kebijakan formulasi hukum pidana saat ini tidak ada nilai permaafan secara murni dari hakim, hukum pidana saat ini masih menggunakan konsep "Tiada Maaf Bagimu" sehingga pidana penjara adalah obat terakhir untuk para pelaku tindak pidana. ${ }^{6}$ Konsep "Tiada Maaf Bagimu" ini terkesan kaku dan tidak progress dalam menyelesaikan

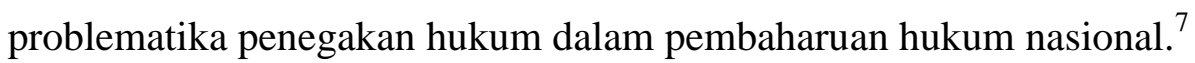

Konsep ini penting untuk dikaji karena di Indonesia saat ini, hakim dalam menjustifikasi adanya suatu pemidanaan terhadap seseorang, formulasinya hanya tindak pidana (syarat obyektif/legalitas) dan kesalahan (syarat subyektif/culpabilitas) tanpa disertakan dengan tujuan dan pedoman pemidanaan. Akibatnya, terdapat kasus-kasus kecil seperti atas nama Aminah $^{8}$

the character of the offender, or the circumstances attendant upon the commission of the offense or thereafter", ketentuan tersebut menyatakan bahwa hakim dapat melakukan permaafan berdasarkan alasan: ringannya tindak pidana yang dilakukan, karakter pribadi si pembuat, atau keadaan-keadaan pada waktu atau setelah delik dilakukan.

${ }^{5}$ Pasal 74 Ayat (1) KUHP Portugal, "When the crime is punishable with imprisonment not superior to 6 (six) months, or only with a fine not superior to 120 days, the court may declare the defendant guilty without applying penalty if: the unlawfulness of the act and the guilt of the agent are minute, the damages have been repaired, or reasons of prevention do not oppose to the dispensation of penalty", ketentuan tersebut menyatakan bahwa hakim dapat melakukan permaafan apabila tindak pidana itu diancam dengan pidana maksimum 6 (enam) bulan penjara; diancam dengan pidana gabungan (kumulasi) antara penjara dan denda yang tidak melebihi 180 denda-harian, alasan permaafan juga berdasarkan: ada kesalahan minimal, kerugian telah dibayar, dan tidak ada faktor-faktor yang menghalangi penyelesaian masalah dengan cara ini.

${ }^{6}$ Aristo Evandy A.Barlian \& Barda Nawawi Arief, "Formulasi Ide Permaafan Hakim (Rechterlijk Pardon) dalam Pembaharuan Sistem Pemidanaan Indonesia”, Jurnal Law Reform, Volume 13 Nomor 1 Tahun 2017, hlm. 33.

${ }^{7}$ Barda Nawawi Arief, Masalah Penegakan Hukum dan Kebijakan Hukum Pidana dalam Penanggulangan Kejahatan, (Jakarta: Kencana, 2014), hlm. 79.

${ }^{8}$ Indonesia, Putusan Pengadilan Negeri Purwokerto Nomor: 247/PID.B/2009/PN.PWT. 
dan Rizal $^{9}$ yang putusannya bertentangan dengan nilai-nilai kemanusiaan yang hidup dalam masyarakat. Kedua putusan itu bertentangan dengan "insignificant principle", ${ }^{10}$ di mana menurut prinsip ini, apabila suatu perbuatan walaupun sudah memenuhi unsur tindak pidana, namun apabila tidak signifikan dengan karakteristik/sifat hakiki dari suatu tindak pidana, tidaklah dapat dinyatakan sebagai tindak pidana. ${ }^{11}$ Adanya pertentangan terhadap insignificant principle juga menjadi alasan diangkatnya permasalahan ini.

Konsepsi Rechterlijk Pardon (Permaafan Hakim) menjadi dasar hakim untuk mempertimbangkan tujuan serta pedoman pemidanaan, disamping tindak pidana (syarat obyektif/legalitas) dan kesalahan (syarat subyektif) dalam menjustifikasi pemidanaan terhadap seseorang. Tujuan dan pedoman pemidanaan telah dirumuskan secara eksplisit di dalam Pasal 55 dan 56 RUU KUHP.

Tujuan pemidanaan dirumuskan secara eksplisit di dalam Pasal 55 Ayat (1) RUU KUHP, yaitu:

1. Mencegah dilakukannya tindak pidana dengan menegakkan norma hukum demi pengayoman masyarakat;

2. Memasyarakatkan terpidana dengan mengadakan pembinaan sehingga menjadi orang yang baik dan berguna;

\footnotetext{
${ }^{9}$ Indonesia, Putusan Pengadilan Tinggi Palu Nomor: 25/PID.SUS/2013/PT.PALU.

${ }^{10}$ Prinsip ini telah digunakan dalam beberapa Kitab Undang-Undang Hukum Pidana (KUHP) asing, dikatakan bahwa walaupun suatu perbuatan memenuhi rumusan delik dalam peraturan, namun tidak merupakan tindak pidana, apabila: Pasal 7 KUHP Bellarus, "no social danger by virtue of it's little singnificance", Pasal 13 KUHP China, "the circumstances are clearly minor and the harm is not great", Pasal 9:2 KUHP Bulgaria, "it's insignificance is not dangerous to society or it's danger to society is obviously insignificant", dan Pasal 18:2 KUHP Armenia, "does not present public danger because of it's little significance, it did not cause significant damage to an individual or a legal entity, to the society or the state".

${ }^{11)}$ Barda Nawawi Arief, "Pembaharuan Sistem Penegakan Hukum dan Pendekatan Religius dalam Konteks SISKUMNAS dan BANGKUMNAS", https://Bardanawawi.wordpress/2009/12/23/pembaharuan-sistem-penegakan-hukum-denganpendekatan-religius-siskumnas-dan-bangkumnas/, diakses tanggal 17 Februari 2018.
} 
3. Menyelesaikan konflik yang ditimbulkan oleh tindak pidana, memulihkan keseimbangan, dan mendatangkan rasa damai dalam masyarakat; dan

4. Membebaskan rasa bersalah pada terpidana.

Pedoman pemidanaan dirumuskan dalam Pasal 56 Ayat (1) RUU KUHP, yaitu:

1. Kesalahan pembuat tindak pidana;

2. Motif dan tujuan melakukan tindak pidana;

3. Sikap batin pembuat tindak pidana;

4. Tindak pidana yang dilakukan apakah direncanakan atau tidak direncanakan;

5. Cara melakukan tindak pidana;

6. Sikap dan tindakan pembuat sesudah melakukan tindak pidana;

7. Riwayat hidup, keadaan sosial, keadaan ekonomi pembuat tindak pidana;

8. Pengaruh pidana terhadap masa depan pembuat tindak pidana;

9. Pengaruh tindak pidana terhadap korban atau keluarga korban;

10. Permaafan dari korban dan/atau keluarganya; dan

11. Pandangan masyarakat terhadap tindak pidana yang dilakukan.

Dalam Pasal 56 Ayat (2) RUU KUHP dikatakan bahwa ringannya perbuatan, keadaan pribadi pembuat, atau keadaan pada waktu dilakukan perbuatan atau yang terjadi kemudian, dapat dijadikan pertimbangan hakim untuk tidak menjatuhkan pidana atau mengenakan tindakan dengan mempertimbangkan segi keadilan dan kemanusiaan.

Konsepsi Rechterlijk Pardon (Permaafan Hakim) ini juga memberikan kebebasan kepada hakim dalam memutus perkara, serta memperluas kewenangan hakim dalam menggali dan mencari keadilan berdasarkan nilainilai yang hidup dalam masyarakat. Berdasarkan uraian di atas, maka diangkatlah penelitian dengan judul "Kebijakan Formulasi terkait Konsepsi 
Rechterlijk Pardon (Permaafan Hakim) dalam Pembaharuan Hukum Pidana di Indonesia".

\section{B. Perumusan Masalah}

Berdasarkan latar belakang di atas, maka rumusan masalah dalam penelitian ini adalah:

1. Bagaimanakah Konsepsi Rechterlijk Pardon (Permaafan Hakim) dalam pembaharuan hukum pidana di Indonesia?

2. Hal-hal apa saja yang menjadi landasan perlunya kebijakan formulasi terkait Konsepsi Rechterlijk Pardon (Permaafan hakim) dalam pembaharuan hukum pidana di Indonesia?

\section{Pembahasan}

\section{A. Konsepsi Rechterlijk Pardon (Permaafan Hakim) dalam Pembaharuan}

\section{Hukum Pidana di Indonesia}

Pembaharuan Hukum Pidana pada hakikatnya mengandung makna, suatu upaya untuk melakukan reorientasi dan reformasi hukum pidana yang melandasi kebijakan sosial, kebijakan kriminal dan kebijakan penegakan hukum di Indonesia. ${ }^{12}$ Pembaharuan hukum pidana harus disertai pula dengan pembaharuan ilmu pengetahuan tentang hukum pidananya. Hal tersebut berarti, pembaharuan hukum pidana tidak hanya mencakup substansi hukum (legal substance reform) harus disertai pula dengan pembaharuan budaya hukum masyarakat (legal culture reform) dan pembaharuan struktur atau perangkat hukumnya (legal structure reform). ${ }^{13}$ Hal ini sejalan dengan teori sistem hukum (legal system) dari Lawrence M. Friedman, di mana ia mengatakan "The elements of a Legal System are Substance, Structure,

\footnotetext{
${ }^{12}$ Barda Nawawi Arief, Bunga Rampai Kebijakan Hukum Pidana: Perkembangan Penyusunan Konsep KUHP baru, cetakan ke-7, (Jakarta: Kencana Prenamedia Group, 2014), hlm. 29.

${ }^{13}$ Barda Nawawi Arief, Beberapa Aspek Kebijakan Penegakan dan Pengembangan Hukum Pidana, (Bandung: Citra Aditya Bakti, 1998), hlm. 133.
} 
Culture, and Impact". ${ }^{14}$ Pembaharuan hukum pidana tentunya juga mencakup pembaharuan sistem hukum pidana. Penelitian ini akan memfokuskan pada salah satu aspek dari sistem hukum yaitu, substansi hukum di mana pembaharuan hukum pidana yang dilakukan adalah memunculkan Konsepsi Rechterlijk Pardon (Permaafan Hakim ke dalam RUU KUHP.

Dalam melakukan pembaharuan hukum pidana, jalan yang dapat ditempuh adalah melalui kebijakan hukum pidana atau politik hukum pidana. Kebijakan hukum pidana berarti, usaha mewujudkan peraturan perundang-undangan pidana yang sesuai dengan keadaan dan situasi pada suatu waktu dan untuk masa-masa yang akan datang. Kebijakan hukum pidana juga mengandung arti bagaimana mengusahakan atau membuat dan merumuskan suatu perundangundangan pidana yang baik. ${ }^{15}$

Kebijakan hukum pidana tediri dari 3 (tiga) tahapan, tahapan formulasi yaitu tahap pembentukan hukum in abstracto oleh badan pembuat undangundang, tahap ini disebut dengan tahap kebijakan legislatif, kemudian tahapan aplikasi yaitu tahap penerapan hukum pidana oleh aparat penegak hukum mulai dari kepolisian sampai pengadilan, tahap ini disebut tahap kebijakan yudikatif, dan yang terakhir adalah tahapan eksekusi, yaitu tahap pelaksanaan hukum pidana secara konkrit oleh aparat-aparat pelaksana pidana, tahap ini dapat disebut juga sebagai kebijakan eksekutif atau administatif. ${ }^{16}$ Berkaitan dengan permasalahan yang diteliti, Konsepsi Rechterlijk Pardon (Permaafan Hakim), saat ini berada pada tahapan formulasi, di mana konsepsi ini telah dimasukan oleh pembentuk undang-undang ke dalam RUU KUHP, yaitu diatur dalam Pasal 55 dan Pasal 56 RUU KUHP.

\footnotetext{
${ }^{14}$ Lawrence M.Friedman, American Law, Cetakan ke-1, (Canada: Stoddart, 1984), hlm. 7. Terjemahan dalam bahasa Indonesia "Elemen-elemen dari Sistem Hukum adalah Substansi, Struktur, Budaya, Pengaruh".

${ }^{15}$ Barda Nawawi Arief, Bunga Rampai..., Op.Cit., hlm. 27.

${ }^{16}$ Lilik Mulyadi, Bunga Rampai Hukum Pidana Perspektif Teoritis dan Praktek, (Bandung: PT.Alumni, 2008), hlm. 391.
} 
Hakim dalam menjustifikasi adanya suatu pemidanaan terhadap seseorang di Indonesia saat ini, formulasinya hanya tindak pidana (syarat obyektif/legalitas) dan kesalahan (syarat subyektif/culpabilitas) tanpa disertakan dengan tujuan dan pedoman pemidanaan. Pemikiran seperti ini masih mengikuti konsep zaman kolonial dan sudah tidak lagi selaras dengan perkembangan masyarakat di Indonesia. Konsepsi rechterlijk pardon (permaafan hakim) menjadi dasar hakim untuk mempertimbangkan tujuan serta pedoman pemidanaan, disamping tindak pidana (syarat obyektif/legalitas) dan kesalahan (syarat subyektif) dalam menjustifikasi pemidanaan terhadap seseorang. Tujuan pemidanaan dirumuskan secara eksplisit di dalam Pasal 55 Ayat (1) RUU KUHP, yaitu:

1. Mencegah dilakukannya tindak pidana dengan menegakkan norma hukum demi pengayoman masyarakat;

2. Memasyarakatkan terpidana dengan mengadakan pembinaan sehingga menjadi orang yang baik dan berguna;

3. Menyelesaikan konflik yang ditimbulkan oleh tindak pidana, memulihkan keseimbangan, dan mendatangkan rasa damai dalam masyarakat; dan

4. Membebaskan rasa bersalah pada terpidana.

Tujuan dari pidana diatas mengandung nilai kemasyarakatan yang sesuai dengan karakter bangsa Indonesia (Pancasila), selain itu tujuan diatas lebih integratif dengan lebih berorientasi pada pelaku tindak pidana dibandingkan tindak pidana. ${ }^{17}$ Pasal 55 Ayat (2) RUU KUHP juga tidak kalah penting dalam mengkonstruksi tujuan pemidanaan karena disebutkan bahwa "pemidanaan tidak dimaksudkan untuk menderitakan dan merendahkan martabat manusia”, hal ini menunjukan bahwa tujuan pemidanaan dalam RUU KUHP sangat berkemanusiaan dan memungkinkan adanya permaafan oleh hakim, hal ini

\footnotetext{
${ }^{17)}$ Aristo Evandy A.Barlian dan Barda Nawai Arief, Op.Cit., hlm. 35.
} 
sejalan dengan Sila ke-2 Pancasila yang sangat menunjung tinggi nilai kemanusiaan.

Pedoman pemidanaan dirumuskan dalam Pasal 56 Ayat (1) RUU KUHP, yaitu:

1. Kesalahan pembuat tindak pidana;

2. Motif dan tujuan melakukan tindak pidana;

3. Sikap batin pembuat tindak pidana;

4. Tindak pidana yang dilakukan apakah direncanakan atau tidak direncanakan;

5. Cara melakukan tindak pidana;

6. Sikap dan tindakan pembuat sesudah melakukan tindak pidana;

7. Riwayat hidup, keadaan sosial, keadaan ekonomi pembuat tindak pidana;

8. Pengaruh pidana terhadap masa depan pembuat tindak pidana;

9. Pengaruh tindak pidana terhadap korban atau keluarga korban;

10. Permaafan dari korban dan/atau keluarganya; dan

11. Pandangan masyarakat terhadap tindak pidana yang dilakukan.

Dalam Pasal 56 Ayat (2) RUU KUHP dikatakan bahwa ringannya perbuatan, keadaan pribadi, keadaan saat terjadi tindak pidana atau yang terjadi kemudian, dapat dijadikan pertimbangan hakim untuk tidak menjatuhkan pidana atau mengenakan tindakan dengan mempertimbangkan segi keadilan dan kemanusiaan. Hal ini berkaitan erat dengan sistem pemidanaan, di mana dengan adanya Konsepsi Rechterlijk Pardon (Permaafan Hakim), maka hakim dalam menjustifikasi pemidanaan terhadap seseorang, hakim harus mempertimbangkan tindak pidana, kesalahan serta tujuan dan pedoman pemidanaan. Apabila hakim memandang bahwa orang tersebut tidak harus dijatuhkan pidana, maka hakim dalam memberi maaf kepada pelaku tindak pidana. 
Andi Hamzah ${ }^{18}$ mengatakan bahwa intisari dari adanya konsepsi ini, nantinya ketika dakwaan Jaksa Penuntut Umum terbukti secara sah dan meyakinkan dan diberi permaafan oleh Hakim, maka pelaku tindak pidana tidak dipidana atau dihukum. Mudahnya, bentuk putusan dari permaafan hakim nantinya adalah putusan bersalah tanpa pidana (a guilty verdict without punishment).

Konsepsi rechterlijk pardon (permaafan hakim) pada hakikatnya dilatarbelakangi oleh ide fleksibelitas untuk menghindari kekakuan. Konsepsi Rechterlijk Pardon (Permaafan hakim) dapat dipandang sebagai "penjaga gawang terakhir" atas suatu perkara yang mengganggu keadilan di masyarakat. Dapat pula dikatakan, bahwa adanya pedoman permaafan hakim itu berfungsi sebagai suatu "katup/klep pengaman" (Veligheids-klep) atau "pintu darurat" (nooddeur). 19

Munculnya tujuan dan pedoman pemidanaan sebagai syarat menjatuhkan pemidanaan, maka hakim diberikan suatu ruang untuk melakukan permaafan kepada pelaku tindak pidana yang apabila pemidanaan itu dijatuhkan, maka tidak sesuai dengan tujuan dari penjatuhan pidana itu sendiri. Permaafan yang dimaksud merupakan suatu bentuk pengampunan/pembebasan dari kesalahan yang dilakukan. Sebagai bentuk pengampunan, maka dengan adanya permaafan, seseorang yang bersalah tidak dijatuhi hukuman atau tidak perlu merasakan hukuman. ${ }^{20}$

Pada prinsipnya, KUHP tidak mengatur tentang permaafan oleh hakim. Hal ini tidak mengherankan karena Kitab Undang-Undang Hukum Pidana sendiri merupakan sebuah sistem pemidanaan (substantif) yang kaku dan bertolak dari tiga masalah hukum pidana, yaitu tindak pidana, kesalahan dan

\footnotetext{
${ }^{18}$ Andi Hamzah, wawancara, Kediaman Andi Hamzah di Jakarta Selatan, DKI Jakarta, 30 April 2018.

${ }^{19}$ Barda Nawawi Arief, Tujuan dan Pedoman Pemidanaan: Perspektif Pembaharuan \& Perbandingan Hukum Pidana, Cetakan ke-3, (Semarang: Pustaka Magister Semarang, 2011), hlm. 15.

${ }^{20}$ Ibid., hlm. 8.
} 
pidana. ${ }^{21}$ Formula seperti ini, maka tidak tergambar adanya variabel tujuan pemidanaan, karena tidak dirumuskan secara eksplisit dalam KUHP, sehingga terkesan tujuan berada diluar sistem. Dengan model demikian, seolah-olah dasar pembenaran adanya pidana hanya terletak pada tindak pidana dan kesalahan, oleh karena itu seolah-olah pemidanaan dianggap sebagai konsekuensi absolut yang harus ada, apabila kedua syarat ini terbukti. Kerangka berpikir seperti ini memberikan suatu legitimasi bahwa KUHP saat ini bersifat kaku.

Penegasan norma "tujuan pemidanaan" akan merubah bentuk skema pemidanaan dengan ditambahnya tujuan pemidanaan selain dari tindak pidana dan kesalahan. Apabila model ini diterapkan maka pelaku yang dimaafkan dan tidak dipidana akan mempunyai tempat dalam sistem peradilan pidana. Dengan demikian, Konsepsi Rechterlijk Padon (Permaafan Hakim) akan mungkin dapat dilaksanakan oleh hakim. Dimasukannya variabel tujuan di dalam syarat pemidanaan, maka menurut RUU KUHP Indonesia, dasar pembenaran adanya pemidanaan, tidak hanya pada tindak pidana dan kesalahan, tetapi juga pada tujuan/pedoman pemidanaan. Mengingat tujuan dan pedoman pemidanaan, maka dalam kondisi tertentu hakim tetap diberi kewenangan untuk memberi maaf dan tidak menjatuhkan pidana atau tindakan apapun, walaupun tindak pidana dan kesalahan telah terbukti. Dapat dikatakan bahwa secara konseptual telah ada pergeseran yang sebelumnya bersifat kaku/absolut berubah menjadi model keseimbangan yang fleksibel. ${ }^{22}$

Formulasi yang mengedepankan fleksibilitas dalam penjatuhan pidana ini tidak ditemukan dalam KUHP Indonesia saat ini, karena KUHP Indonesia masih mempertahankan pola konvensional yaitu hanya mempertimbangkan tindak pidana dan kesalahan sehingga permaafan oleh hakim masih dianggap sesuatu yang janggal. Munculnya penegasan norma tujuan pemidanaan dalam

\footnotetext{
${ }^{21}$ Ibid., hlm. 10.
}

${ }^{22}$ Ibid., hlm. 14. 
RUU KUHP, maka skema pemidanaan akan terlihat pada gambar dibawah ini: ${ }^{23}$

\section{Gambar 1. Formulasi Pemidanaan dalam RUU KUHP}

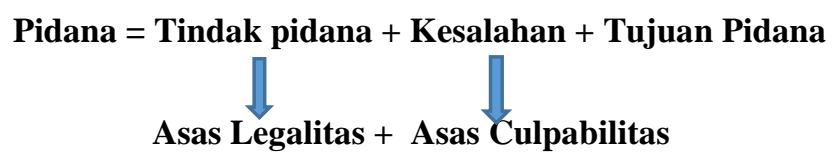

Gambar diatas terlihat, bahwa tujuan pidana menjadi syarat berlakunya suatu pemidanaan. Dengan adanya tujuan dalam pemidanaan jelas akan menciptakan karakter hakim yang lebih menahan nafsu untuk memenjarakan dan akan lebih mewujudkan efektivitas pemidanaan dengan memperhatikan nilai-nilai integral, progesivitas dan individual pelaku sesuai dengan sistem hukum nasional yaitu Pancasila.

Konsepsi Rechterlijk Pardon (Permaafan Hakim) ini awalnya muncul dalam KUHP Belanda, yaitu terdapat dalam Pasal 9 WvS Belanda, dikatakan bahwa hakim diberi wewenang untuk tidak memidana suatu perbuatan, jadi sekalipun pelaku telah memenuhi unsur kesalahan sebagaimana yang dirumuskan dalam ketentuan tindak pidana tapi hakim dapat memberikan permaafan pada pelaku. Dalam memberikan permaafan, hakim mempertimbangkan hal-hal ringannya tindak pidana yang dilakukan, karakter pribadi si pembuat, dan keadaan-keadaan pada waktu atau setelah tindak pidana dilakukan. Ketentuan dalam Pasal $9 \mathrm{WvS}$ Belanda tidak memiliki perbedaan yang signifikan dengan Pasal 56 Ayat (2) RUU KUHP Indonesia, namun dalam RUU KUHP dimasukan juga nilai keadilan dan kemanusiaan dalam mempertimbangkan pemberian permaafan kepada pelaku tindak pidana. Hal ini tentunya disesuaikan dengan nilai-nilai filosofis bangsa

\footnotetext{
${ }^{23}$ Aristo Evandy A.Barlian..., Op.Cit., hlm. 38.
} 
Indonesia, di mana Sila ke-2 Pancasila menyatakan bahwa "Kemanusiaan yang adil dan beradab", ketentuan tersebut sangat menunjung tinggi nilai kemanusiaan. Dimasukannya nilai kemanusiaan ke dalam syarat pemberian permaafan ini tentunya sejalan dengan Sila ke-2 Pancasila.

Negara lain yang mengatur mengenai Konsepsi Rechterlijk Pardon (Permaafan Hakim) adalah Negara Portugal, yaitu terdapat dalam Pasal 74 Ayat (1) KUHP Portugal, di mana hakim dapat memberikan permaafan kepada pelaku tindak pidana dengan mempertimbangkan tindak pidana itu diancam dengan pidana maksimum 6 (enam) bulan penjara; diancam dengan pidana gabungan (kumulasi) antara penjara dan denda yang tidak melebihi 180 denda-harian, alasan permaafan juga berdasarkan: ada kesalahan minimal, kerugian telah dibayar, dan tidak ada faktor-faktor yang menghalangi penyelesaian masalah dengan cara ini.

Terdapat perbedaan yang cukup signifikan dalam mempertimbangkan pemberian maaf kepada pelaku tindak pidana antara KUHP Portugal dan RUU KUHP Indonesia. RUU KUHP Indonesia tidak memasukan secara eksplisit ancaman maksimal pidana penjara dalam pemberian permaafan, namun ketentuan ini dapat ditafsirkan sama dengan syarat "ringannya perbuatan" dalam memberikan permaafan, karena salah satu karakteristik dalam menentukan ringannya perbuatan adalah dengan melihat ancaman pidana yang diberikan terhadap tindak pidana yang bersangkutan. Syarat lain yang diatur dalam KUHP Portugal adalah kesalahan yang minimal, ini telah dimasukan ke dalam RUU KUHP Indonesia, yaitu syarat kesalahan pelaku tindak pidana yang harus ringan dan tidak berat. Syarat selanjutnya adalah kerugian yang telah dibayar, dalam RUU KUHP Indonesia tidak memasukan secara eksplisit hal ini sebagai syarat memberikan permaafan. Syarat terakhirnya adalah tidak ada faktor-faktor yang menghalangi penyelesaian masalah dengan cara ini, ketentuan seperti ini tentunya menimbulkan multitafsir dalam mengartikan 
maksud ketentuan tersebut dan RUU KUHP Indonesia tidak memasukan hal itu sebagai syarat memberikan permaafan.

Salah satu teori tujuan pemidanaan dalam hukum pidana adalah Restoractive Justice (Keadilan Restoratif), ini dipahami sebagai bentuk pendekatan penyelesaian perkara menurut hukum pidana dengan melibatkan pelaku kejahatan, korban, keluarga korban atau pelaku dan pihak lain yang terkait untuk mencari penyelesaian yang adil dengan menekankan pada pemulihan kembali pada keadaan semula dan bukan pembalasan. ${ }^{24}$ Ramburambu dalam memberikan permaafan oleh hakim ini, salah satunya adalah mendapatkan permaafan dari korban dan/atau keluarga korban. Dapat dikatakan bahwa Konsepsi Rechterlijk Pardon (Permaafan Hakim) ini sejalan dengan salah satu teori tujuan pemidanaan dalam hukum pidana yaitu Restoractive Justice (Keadilan Restoratif).

Perlu kita sadari, bahwa syarat dalam memberikan permaafan oleh hakim kepada pelaku tindak pidana berdasarkan RUU KUHP yaitu ringannya perbuatan, keadaan pribadi pembuat, atau keadaan pada waktu dilakukan perbuatan atau yang terjadi kemudian, serta segi kemanusiaan dan keadilan, tidak ada ketegasan norma mengenai apa yang dimaksudkan dengan syarat yang disebutkan di atas dalam RUU KUHP. Ketidakpastian ini merupakan bentuk kelemahan dari pengaturan akan Konsepsi Rechterlijk Pardon (Permaafan Hakim) yang akan bertentangan dengan salah satu dari nilai dasar hukum yaitu kepastian hukum.

\section{B. Hal-hal yang menjadi Landasan Perlunya Konsepsi Rechterlijk Pardon} (Permaafan Hakim) dalam Pembaharuan Hukum Pidana di Indonesia

Dalam pembahasan kali ini, akan dibahas mengenai apa yang menjadi landasan perlunya Konsepsi Rechterlijk Pardon (Permafan Hakim) dalam pembaharuan hukum pidana di Indonesia, tepatnya telah dimasukan ke dalam

\footnotetext{
${ }^{24}$ Eddy O. S. Hiariej, Prinsip-Prinsip Hukum Pidana, edisi revisi, (Yogyakarta: Cahaya Atma Pustaka, 2016), hlm. 45.
} 
RUU KUHP. Dimunculkannya konsepsi ini ke dalam RUU KUHP tentunya bukan tanpa landasan yang kuat, karena lahirnya suatu norma dalam peraturan perundang-undangan pasti didasarkan pada sesuatu yang jelas.

Terdapat beberapa landasan perlunya Konsepsi Rechterlijk Pardon (Permafan Hakim) dimasukan ke dalam RUU KUHP, salah satunya adalah landasan filosofis. Pancasila serta Pembukaan UUD harus dijadikan tolak ukur dalam menilai pentingnya Konsepsi ini. Alinea ke-1 Pembukaan UUD dan Pasal 1 Aturan Peralihan UUD 1945 menjadi landasan kuat mengapa penting dilakukan pembaharuan hukum pidana dan penegasan norma mengenai Konsepsi Rechterlijk Pardon (Permaafan Hakim) ke dalam RUU KUHP merupakan salah satu bentuk dari pembaharuan hukum pidana.

Salah satu syarat dalam memberikan permaafan kepada pelaku tindak pidana adalah memperhatikan nilai-nilai kemanusiaan. Ideologi negara kita yaitu Pancasila, khususnya sila ke-2 menyatakan bahwa "Kemanusiaan yang adil dan beradab", ketentuan tersebut sangat menunjung tinggi nilai kemanusiaan. Dimasukannya nilai kemanusiaan ke dalam syarat pemberian permaafan ini tentunya sejalan dengan Sila ke-2 Pancasila. Konsepsi ini juga dianggap sesuai dengan nilai-nilai hukum yang hidup dan nilai hukum nasional yang lebih berorientasi pada nilai Pancasila.

Landasan yuridis merupakan salah satu landasan yang penting mengapa perlu penegasan Konsepsi Rechterlijk Pardon (Permaafan Hakim) menjadi norma yaitu dimasukan dalam RUU KUHP. Landasan yuridis ini sangat erat kaitannya dengan salah satu tujuan dari Konsepsi ini yaitu koreksi yudisial terhadap asas legalitas. ${ }^{25}$ Pertanyaannya ditimbul di sini adalah, bagaimana apabila seseorang terbukti melakukan tindak pidana, namun setelah hakim melakukan pertimbangan terhadap ringannya perbuatan, keadaan pelaku tindak pidana, keadaan pada saat tindak pidana dilakukan atau keadaan setelah

\footnotetext{
${ }^{25}$ Adhery Ardhan Saputro, "Konsepsi Rechterlijk Pardon atau Permaafan Hakim dalam Rancangan KUHP”, Mimbar Hukum, Volume 18 Nomor 1 Tahun 2016, hlm. 66.
} 
tindak pidana dilakukan serta nilai kemanusiaan dan keadilan, hakim memandang bahwa perbuatan yang dilakukan oleh pelaku tindak pidana tidak harus dijatuhkan pidana, ini menjadi persoalan karena hakim tidak diberikan ruang oleh pembentuk undang-undang untuk melakukan permaafan dengan kata lain terjadi kekosongan hukum. Oleh karena itu, dengan adanya penegasan norma mengenai Konsepsi Rechterlijk Pardon (Permaafan Hakim), maka hakim dapat melakukan permaafan kepada pelaku tindak pidana yang dipandang tidak harus dijatuhkan pidana, dengan kata lain hakim dapat memberikan permaafan apabila penjatuhan pidana itu tidak sesuai dengan tujuan serta pedoman pemidanaan.

Konsepsi Rechterlijk Pardon (Permaafan Hakim) ini juga sejalan dengan salah satu prinsip dalam perkembangan global hukum pidana, yaitu Insignificant Principle, di mana prinsip ini mengatakan bahwa apabila suatu perbuatan walaupun sudah memenuhi unsur tindak pidana, namun apabila tidak signifikan dengan karakteristik/sifat hakiki dari suatu tindak pidana, tidaklah dapat dinyatakan sebagai tindak pidana. ${ }^{26}$ Artinya, ketika suatu perbuatan itu tidak signifikan untuk dipidana, maka hakim dapat melakukan permaafan kepada pelaku yang telah terbukti melakukan tindak pidana.

Landasan lain yang penting adalah landasan teoretis, di mana dibagi lagi menjadi beberapa landasan, yaitu landasan politis, landasan adaptif, dan landasan sosiologis. Landasan politis mengapa dilakukan penegasan norma terhadap Konsepsi Rechterlijk Pardon (Permaafan hakim) yaitu karena Negara Indonesia yang telah 60 (enam puluh) puluh tahun lebih merdeka adalah wajar apabila mempunyai hukum pidana sendiri yang diciptakannya sendiri oleh karena hal ini merupakan simbol kebanggaan dari negara yang

\footnotetext{
${ }^{26}$ Barda Nawawi Arief, "Pembaharuan Sistem Penegakan Hukum dan Pendekatan Religius dalam Konteks SISKUMNAS dan BANGKUMNAS", https://Bardanawawi.wordpress/2009/12/23/pembaharuan-sistem-penegakan-hukum-denganpendekatan-religius-siskumnas-dan-bangkumnas/, diakses tanggal 17 Februari 2018.
} 
telah bebas dari penjajahan, ${ }^{27}$ seperti yang kita ketahui bersama bahwa dimasukannya konsepsi ini ke dalam RUU KUHP merupakan suatu simbol kebanggaan Negara Indonesia karena berani memperbaharui hukum pidana, di mana tidak hanya mengandalkan hukum pidana peninggalan warisan penjajah.

Landasan adaptif merupakan salah satu landasan teoretis mengapa penting penegasan norma terhadap Konsepsi Rechterlijk Pardon (Permaafan Hakim) dalam RUU KUHP. Negara Indonesia merupakan negara yang telah merdeka dan sebagai bangsa yang merdeka, maka bangsa Indonesia tidak dapat lepas dari pergaulan bangsa-bangsa di dunia, oleh karenanya landasan adaptif tidak dapat dikesampingkan, artinya upaya pembaharuan di masa-masa yang akan datang harus dapat menyesuaikan diri dengan perkembangan-perkembangan baru khususnya perkembangan Internasional yang bergerak cepat. ${ }^{28}$

Salah satu ide yang muncul dalam perkembangan internasional Konsepsi Rechterijk Pardon (Permaafan Hakim), di mana konsepsi ini telah dimasukkan ke dalam peraturan hukum pidana berbagai negara, diantaranya negara Belanda dan Portugal. Berdasarkan landasan adaptif ini, maka sudah tepat ketika Negara Indonesia merespon perkembangan yang ada di negara lain dengan memasukan Konsepsi Rechterlijk Pardon (Permaafan Hakim) ini ke dalam RUU KUHP sebagai salah satu bentuk pembaharuan hukum pidana.

Landasan adaptif yaitu mengadaptasi perkembangan global juga sejalan dengan apa yang disampaikan oleh Andi Hamzah, ${ }^{29}$ ia mengatakan bahwa di Belanda saat ini, 60\% (enam puluh persen) perkara pidana tidak lagi diselesaikan oleh Pengadilan, melainkan oleh Jaksa Penuntut Umum di luar pengadilan, di Belanda dikenal dengan istilah afdoening buiten process (penyelesaian perkara di luar pengadilan). Perkara yang diringan diselesaikan di luar pengadilan, perkara ringan yang dimaksud adalah tindak pidana yang

\footnotetext{
${ }^{27}$ Ali Zaidan, Op.Cit.

${ }^{28}$ Muladi, Op.Cit.

${ }^{29}$ Andi Hamzah, wawancara, Kediaman Andi Hamzah di Jakarta Selatan, DKI Jakarta, 30 April 2018.
} 
diancam dengan pidana penjara di bawah 6 (enam) tahun ke bawah dengan cara ganti kerugian oleh pelaku tindak pidana kepada korban. Bentuk lain, apabila perkara ringan tetap diselesaikan di pengadilan, maka hakim dapat memutus dengan rechterlijk pardon (permaafan hakim) dengan memperhatikan ringannya perbuatan, keadaan pelaku tindak pidana dan keadaan sebelum atau setelah tindak pidana itu dilakukan.

Secara sosiologis, dengan dimasukannya Konsepsi Rechterlijk Pardon (Permaafan Hakim) ke dalam RUU KUHP tentunya mencerminkan kehendak untuk memenuhi kebutuhan hukum masyarakat yang sudah diupayakan sejak 60 (enam puluh) lebih tahun yang lalu. Kebutuhan ini didasarkan pada nilainilai dari suatu bangsa yang merdeka dan berdaulat. Kondisi internal masyarakat Indonesia yang berkembang seiring perkembangan yang terjadi di dunia internasional serta adanya tuntutan akan kepastian hukum dan keadilan yang begitu kuat, menyebabkan beberapa rumusan hukum pidana yang dimuat dalam KUHP tidak lagi dapat dijadikan dasar hukum untuk mengatasi problematika yang timbulkan dalam masyarakat.

Dapat kita lihat dalam beberapa kasus yang digunakan untuk mendukung penelitian ini, di mana kasus tersebut masih menggunakan konsepsi peninggalan warisan kolonial, hasilnya banyak masyarakat Indonesia yang merasa bahwa dalam kasus tersebut tidak mencapai tujuan hukum yang adil. Kasus atas nama Aminah atau dikenal dengan Nenek Minah misalnya, ia hanya mencuri tiga buah kakao untuk melangsungkan hidupnya tanpa ia ketahui bahwa pohon kakao itu ada pemiliknya, kemudian ia diputus bersalah oleh Majelis Hakim Pengadilan Negeri Purwokerto dengan Putusan Nomor 247/PID.B/2009/PN.PWT. Apabila pada saat itu formulasi mengenai Konsepsi Rechterlijk Pardon (Permaafan Hakim) telah ada, dengan memperhatikan ringannya perbuatan dan keadaan ekonomi dan sosial dari Aminah, maka seharusnya Aminah dapat diberikan permaafan oleh hakim, 
karena Aminah juga telah mengakui perbuatannya sehingga tidak ada urgensi untuk memidana Aminah.

Selanjutnya, kasus atas nama Rizal, di mana kasus ini mendapat sorotan dari masyarakat, di mana Rizal ini merupakan anak berumur 16 tahun dan dikenal sebagai anak yang baik di kampungnya. Tahun 2013 menjadi tahun terburuknya, di mana ia diputus bersalah melakukan pencurian oleh Pengadilan Tinggi Palu dengan Putusan Nomor 25/PID.SUS/2013/PT.PALU. Diketahui bahwa barang curian itu hendak dikembalikan kepada pemiliknya, namun barang tersebut telah hilang, dengan kata lain Rizal telah mengakui perbuatannya, bahkan korban juga telah memaafkan perbuatan Rizal. Walaupun putusan hakim hanya berisi penyerahan kepada negara untuk melakukan pendidikan, pembinaan, dan latihan kerja, namun tidak ada nilai permaafan oleh hakim kepada Rizal karena dalam pertimbangannya hakim masih ingin memberikan efek jerah kepada Rizal. Apabila pada saat itu formulasi mengenai Konsepsi Rechterlijk Pardon (Permaafan Hakim) telah ada, maka hakim dapat diberi ruang untuk melakukan permaafan, karena salah satu pedoman dalam memberikan permaafan adalah memperhatikan pengaruh pemidanaan untuk masa depan serta permaafan dari korban dan/atau keluarganya. Ketika pemidanaan yang diberikan kepada Rizal itu dipandang menghambat perkembangan masa depannya serta dari pihak korban juga telah memberikan maaf kepada Rizal, seharusnya Rizal dapat diberikan permaafan oleh hakim, karena tidak ada urgensi untuk memidana Rizal.

Tujuan dari adanya Konsepsi Rechterlijk Pardon (Permaafan Hakim) adalah sebagai berikut: ${ }^{30}$

1. Dalam rangka alternatif penjara pendek (alternative penal measures to imprisonment);

2. Koreksi yudisial terhadap asas legalitas (judicial corrective to the legality principle);

3. Mencegah pemidanaan yang tidak diperlukan.

\footnotetext{
${ }^{30}$ Adhery Ardhan Saputro, Op.Cit.
} 
Berkaitan dengan tujuan yang pertama, ketika terpidana telah dijatuhkan pidana penjara pendek misalnya 3 (tiga) bulan, kemudian terpidana itu telah menyelesaikan pidana berupa penjara pendek tersebut, ia dianggap telah menyelesaikan sanksi pidananya, namun bagaimana dengan sanksi sosial, pandangan atau stigma masyarakat terhadap orang tersebut telah buruk, padahal ia hanya melakukan tindak pidana ringan dengan sanksi pidana yang ringan.. Keadaan seperti ini sangat merugikan orang tersebut, oleh karena itu dengan adanya Konsepsi Rechterlijk Pardon (Permaafan Hakim), maka hakim dapat diberikan alternatif lain selain penjatuhan pidana penjara pendek, yaitu dengan memberikan permaafan kepada pelaku tindak pidana tersebut.

Berkaitan dengan tujuan yang kedua, bagaimana apabila seseorang telah terbukti secara sah dan meyakinkan melakukan tindak pidana, namun hakim memandang bahwa orang tersebut tidak harus dijatuhkan pidana, ini menjadi masalah karena hakim tidak diberikan ruang oleh pembentuk undang-undang untuk melakukan permaafan, oleh karenanya dengan adanya Konsepsi Rechterlijk Pardon (Permaafan Hakim), maka hakim dapat melakukan permaafan terhadap orang yang terbukti melakukan tindak pidana namun dipandang tidak harus dijatuhkan pidana.

Tujuan dari Konsepsi Rechterlijk Pardon (Permaafan Hakim) tidak hanya untuk menghindari penjatuhan pidana penjara pendek dan koreksi yudisial terhadap asas legalitas, tetapi juga untuk mencegah pemidanaan yang tidak diperlukan dilihat dari sudut kebutuhan, baik kebutuhan melindungi masyarakat maupun untuk merehabilitasi si pelaku tindak pidana. 


\section{Penutup}

\section{A. Kesimpulan}

Berdasarkan uraian analisis di atas, maka dapat ditarik kesimpulan sebagai berikut:

1. Hakim dalam menjustifikasi adanya suatu pemidanaan terhadap seseorang di Indonesia saat ini, formulasinya hanya tindak pidana (syarat obyektif/legalitas) dan kesalahan (syarat subyektif/culpabilitas), namun dengan adanya Konsepsi Rechterlijk Pardon (Permaafan Hakim) maka selain dua syarat di atas, hakim juga harus mempertimbangkan tujuan serta pedoman pemidanaan. Tujuan serta pedoman pemidanaan telah dimasukan ke dalam Pasal 55 dan Pasal 56 RUU KUHP. Hakim harus mempertimbangkan ringannya perbuatan, keadaan pribadi pembuat, keadaan pada waktu dilakukan perbuatan atau terjadi kemudian, serta mempertimbangkan segi keadilan dan kemanusiaan dan apabila hakim memandang bahwa pelaku tindak pidana itu tidak harus dijatuhkan pidana, maka hakim dapat melakukan permaafan. Intisari dari adanya konsepsi ini, nantinya ketika dakwaan Jaksa Penuntut Umum terbukti secara sah dan meyakinkan dan diberi permaafan oleh hakim, maka pelaku tindak pidana tidak dipidana atau dihukum. Mudahnya, bentuk putusan dari permaafan hakim nantinya adalah putusan bersalah tanpa pidana (a guilty verdict without punishment).

2. Munculnya Konsepsi Rechterlijk Pardon (Permaafan Hakim) ini ke dalam RUU KUHP bukan tanpa landasan yang kuat, salah satunya dipandang sebagai respon terhadap perkembangan hukum pidana yang ada di negara lain, diantaranya Negara Belanda dan Negara Portugal. Secara filosofis, yuridis, dan sosiologis, Konsepsi Rechterlijk Pardon (Permaafan Hakim) dianggap sesuai dengan nilai-nilai hukum yang hidup dan nilai hukum nasional yang lebih berorientasi pada nilai Pancasila. Konsepsi Rechterlijk Pardon (Permaafan Hakim) ini juga sejalan dengan salah satu prinsip 
dalam perkembangan global hukum pidana, yaitu Insignificant Principle dan juga tujuan pemidanaan danlam hukum pidana yaitu Restoractive Justice.. Hal tersebut yang menjadi landasan perlunya kebijakan formulasi dalam RUU KUHP terkait Konsepsi Rechterlijk Pardon (Permaafan Hakim) sebagai salah satu bentuk pembaharuan hukum pidana di Indonesia.

\section{B. Saran}

Berdasarkan kesimpulan di atas, maka saran yang dapat diberikan adalah sebagai berikut:

1. Bagi lembaga pembentuk undang-undang (Dewan Perwakilan Rakyat dan Presiden) agar dapat melihat keperluan hukum pidana saat ini, yang memerlukan pembaharuan yang signifikan salah satunya dengan mengesahkan RUU KUHP demi tercapainya sistem peradilan pidana yang lebih efektif di Indonesia. KUHP yang saat ini berlaku dirasa kaku dan tidak memiliki nilai permaafan dalam formulasinya, dengan dimasukannya Konsepsi Rechterlijk Pardon (Permaafan Hakim) maka dalam rangka mencari keadilan masyarakat Indonesia dapat diwujudkan secara nyata.

2. Sebelum lembaga pembentuk undang-undang (Dewan Perwakilan Rakyat dan Presiden) mengesahkan RUU KUHP khususnya yang berkaitan dengan Konsepsi Rechterlijk Pardon (Permaafan Hakim), perlu ada revisi khususnya terkait dengan rambu-rambu/pedoman/batasan dalam penjatuhan putusan permaafan, karena dalam RUU KUHP saat ini belum ada penjelasan terkait dengan ringannya perbuatan, keadaan pribadi pembuat, keadaan pada waktu dilakukan perbuatan atau terjadi kemudian, serta segi keadilan dan kemanusiaan. Hal ini bertujuan agar tercapainya kepastian hukum dalam menentukan apakah seorang terdakwa dapat dimaafkan oleh hakim atau tidak. 


\section{Daftar Pustaka}

A. Buku

Arief, Barda Nawawi. Beberapa Aspek Kebijakan Penegakan dan Pengembangan Hukum Pidana. Bandung: Citra Aditya Bakti, 1998.

- Tujuan dan Pedoman Pemidanaan: Perspektif Pembaharuan \& Perbandingan Hukum Pidana. Cetakan ke-3. Semarang: Pustaka Magister Semarang, 2013.

Bunga Rampai Kebijakan Hukum Pidana: Perkembangan Penyusunan Konsep KUHP Baru. Cetakan ke-7. Jakarta: Kencana Prenamedia Groups, 2014. . Masalah Penegakan Hukum dan Kebijakan Hukum Pidana dalam Penanggulangan Kejahatan. Jakarta: Kencana, 2014.

Friedman, Lawrence M. American Law. Canada: Stoddart, 1984.

Hiariej, Eddy O. S. Prinsip-Prinsip Hukum Pidana. Edisi Revisi. Yogyakarta: Cahaya Atma Pustaka, 2016.

Muladi. Proyeksi Hukum Pidana Materiil Indonesia di Masa Datang (Pidato Pengukuhan). Semarang: BP UNDIP, 1995.

Mulyadi, Lilik. Bunga Rampai Hukum Pidana Perspektif Teoritis dan Praktek. Bandung: PT.Alumni, 2008.

Zaidan, Ali. Menuju Pembaharuan Hukum Pidana. Jakarta: Sinar Grafika, 2015.

B. Peraturan Perundang-undangan Nasional

Indonesia. Undang-Undang Dasar Negara Republik Indonesia Tahun 1945, Cetakan keenam. Jakarta: Kepaniteraan dan Sekretariat Jenderal Mahkamah Konstitusi RI, 2016.

. Undang-Undang Republik Indonesia Nomor 1 Tahun 1946 Tentang Peraturan Hukum Pidana (Lembaran Negara Republik Indonesia Tahun 1946 Nomor 9). 
C. Rancangan Undang-undang

Indonesia. Rancangan Kitab Undang-undang Hukum Pidana Indonesia. Edisi Revisi Tahun 2015.

D. Peraturan Perundang-undangan Asing

Belanda. Netherlands Criminal Code. Tahun 2012

Portugal. Portuguese Penal Code. Tahun 2006.

E. Putusan Pengadilan

Indonesia. Putusan Pengadilan Negeri Purwokerto Nomor 247/PID.B/2009/PN.PWT.

\begin{tabular}{cccc} 
Putusan Pengadilan Pinggi Palu & Nomor \\
\hline 25/PID.SUS/2013/PT.PALU. & &
\end{tabular}

F. Jurnal

A.Barlian, Aristo Evandy \& Barda Nawawi Arief. "Formulasi Ide Permaafan Hakim (Rechterlijk Pardon) Dalam Pembaharuan Sistem Pemidanaan Indonesia”. Jurnal Law Reform. Volume 13 No. 1 Tahun 2017.

Saputro, Adhery Ardhan. "Konsepsi Rechterlijk Pardon atau Permaafan Hakim dalam Rancangan KUHP”. Mimbar Hukum. Volume 18 No. 1 Tahun 2016.

G. Artikel Internet

Arief, Barda Nawawi. "Pembaharuan Sistem Penegakan Hukum dengan Pendekatan Religius dalam Konteks SISKUMNAS dan BANGKUMNAS". Tersedia di https://bardanawawi.wordpress.com/2009/12/23/pembaharuan-sistempenegakan-hukum-dengan-pendekatan-religius-dalam-konteks-siskumn 